\title{
Integrating local knowledge with tree diversity analyses to optimize on-farm tree species composition for ecosystem service delivery in coffee agroforestry systems of Uganda
}

\author{
Hannington Bukomeko - Laurence Jassogne $\cdot$ Susan Balaba Tumwebaze • \\ Gerald Eilu $\cdot$ Philippe Vaast
}

Received: 16 December 2016/Accepted: 5 December 2017/Published online: 8 December 2017

(C) The Author(s) 2017. This article is an open access publication

\begin{abstract}
Coffee agroforestry systems deliver ecosystem services (ES) critical for rural livelihoods like food but also disservices that constrain livelihoods like fostering coffee-pests. Since such ES are treebased, maximizing ES and limiting constraints requires knowledge on optimizing on-farm tree composition especially trees adapted to local conditions. The study was in three sites along a rainfall gradient in Central Uganda where we: assessed tree diversity in coffee agroforestry; ranked tree suitability for providing ES according to farmers' knowledge; and then proposed an approach for optimizing on-farm tree composition for delivery of ES. We collected data on tree diversity and, farmers' knowledge of tree species and the ES they provide. Farmers ranked ES in order
\end{abstract}

H. Bukomeko $(\bowtie) \cdot$ L. Jassogne

International Institute of Tropical Agriculture (IITA), P.O. Box 7878, Kampala, Uganda

e-mail: hbukomeko@gmail.com

L. Jassogne

e-mail: ljassogne@gmail.com;

ljassogne@cgiar.org

H. Bukomeko · S. B. Tumwebaze · G. Eilu

Department of Forestry, Biodiversity and Tourism,

Makerere University, P.O. BOX 7062, Kampala, Uganda

e-mail: balaba2@yahoo.com

G. Eilu

e-mail: gerald.eilu@gmail.com of importance to their livelihoods ('Needs rank') and ranked trees according to suitability for providing ES. Using Bradley Terry modeling, we grouped trees into 'ES groups' according to suitability for providing different ES and ranked 'ES groups' according to tree diversity ('Diversity rank'). Tree-suitability for providing $\mathrm{ES}$ and importance of $\mathrm{ES}$ to farmers varied with rainfall regime but tree diversity did not match farmers' needs for ES. We propose the FaD-FaN (matching farm tree diversity to farmers' needs) approach for optimizing tree species composition with respect to tree-suitability for farmers' priority ES. Farmers locally prioritize ES needed and identify trees that best serve such ES. The approach then focuses on modifying on-farm tree diversity to match/suit

P. Vaast

UMR Eco \& Sols, Centre de Coopération Internationale en Recherche Agronomique pour le Développement (CIRAD), 2 place Viala, 34060 Montpellier Cedex 2,

France

e-mail: p.vaast@cgiar.org

P. Vaast

World Agroforestry Centre (ICRAF), United Nations Avenue, Gigiri, PO Box 30677-00100, Nairobi, Kenya 
farmers' priority ES. The FaD-FaN approach caters for varying socio-ecological conditions; it's adaptable for other coffee and cocoa-growing areas worldwide.

Keywords Coffee $\cdot$ Shade trees $\cdot$ Tree diversification · Farmers' knowledge · Farmers' needs $\cdot$ Climate Change

\section{Introduction}

Globally, areas suitable for coffee production will shrink up to $40 \%$ if temperatures increase by $2{ }^{\circ} \mathrm{C}$ by 2050 and $4{ }^{\circ} \mathrm{C}$ by 2100 (IPCC 2014; Adhikari et al. 2015). Coffee production will remain possible in some areas of East Africa but sustaining or improving upon current levels of production will require adaptation (Bunn et al. 2015). A commendable adaptation option is the promotion of agro-biodiversity and delivery of ecosystem services (ES) from ecosystem-based adaptation practices (Noordwijk et al. 2011). Ecosystembased adaptation practices can deliver an optimized set of ES that can support farmers to adapt to, and mitigate climate change effects and improve livelihoods: The most promising ecosystem-based adaptation practice in coffee production is agroforestry (Vignola et al. 2015). However, not all agroforestry options fit everywhere (Coe et al. 2014). Moreover, the current state of knowledge fails to demonstrate how to optimize delivery of ES through agroforestry (Mbow et al. 2014a). Optimizing ES delivery is critical for context-specific agroforestry options including synergies between climate change mitigation and adaptation (Rahn et al. 2014; Vaast et al. 2016). Since biodiversity underpins ES delivery (Cardinale et al. 2012), targeted changes in tree diversity can influence ES derived from coffee agroforestry (Cardinale et al. 2011; de Beenhouwer et al. 2013). We hypothesize that farms should have more tree diversity-hence more functional stability (Leary and Petchey 2009; Mori et al. 2013) - targeted to deliver priority ES. This study proposes an approach for optimizing on-farm tree composition for ES delivery. The study: assessed tree diversity in coffee farms; used farmers' knowledge to evaluate tree suitability for providing ES; and proposes an approach for optimizing on-farm tree composition to deliver a locally-adapted set of ES that meets farmers' prioritized needs.

\section{Methods}

Site description

The study covered the greater Luweero region (Fig. 1) of Central Uganda (between $31^{\circ} \mathrm{E}-32^{\circ} \mathrm{E}$ and $0.5 \mathrm{~N}-$ $1.3^{\circ} \mathrm{N}$ ) with an area of approximately $9000 \mathrm{~km}^{2}$. The greater Luweero region receives a bimodal rainfall with peaks in March to May and October to November. Annual rainfall varies from $700 \mathrm{~mm}$ in the North up to more than $1300 \mathrm{~mm}$ in the South (Lwasa et al. 2011; Funk et al. 2012). Consequently, the rainfall gradient was divided into three zones: a high rainfall zone $(>1300 \mathrm{~mm})$, a moderate rainfall zone $(1100-1300 \mathrm{~mm})$ and a low rainfall zone $(<1100 \mathrm{~mm})$. Across the rainfall gradient, most of the Robusta coffee is grown in CAFS. The present study used this rainfall gradient as a proxy for a climatic gradient to generate insights into possible climate change effects on tree suitability for ES.

\section{Data collection}

Stratified random sampling was used to select study farms where rainfall zoning was the stratum and within each rainfall zone, we randomly chose 100 coffee farming households totaling to 300 households that we studied in two phases. In phase one, we randomly selected 150 coffee farming households (50 per rainfall zone) and collected tree diversity data from their coffee farms through tree-inventories. During the inventories, we identified tree species by local names in Luganda (Language in central Uganda) and corresponding botanical names from tree identification guides e.g., Katende et al. (1995). For every tree species encountered, we made a technical sheet with photos showing its bole, fruits, leaves, branching, flowers, bark, and local names. In phase two, we conducted a cross-sectional household survey of 300 coffee farming households (including 150 of phase one) and assessed farmers' local knowledge of trees using ranking interviews. The interview had two stages. First, we presented farmers with 12 tree-based ES that they consider key services for their livelihoods: coffee yield increase (some trees associated 


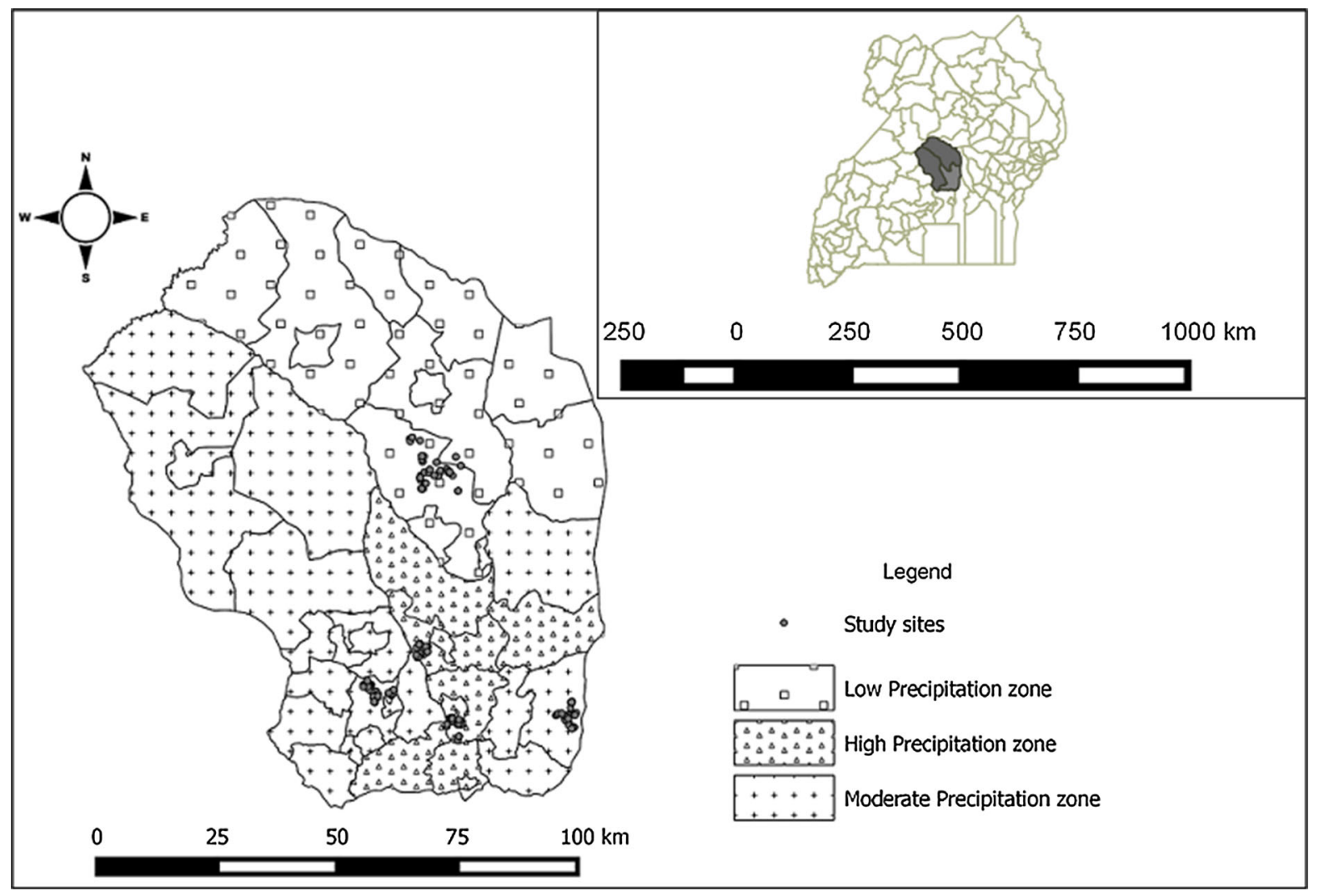

Fig. 1 Map of study area showing the Luweero region and the different rainfall (precipitation) zones of the study area

with increased coffee yield); soil moisture preservation (some trees associated with soil water conservation); leaf litter provision (some trees drop a lot of litter); tree leaf decomposition (some tree-leaves decompose fast); food provision (some trees have edible parts); provision of quality shade for coffee (some trees have better shade for coffee); microclimatic temperature buffering (some trees cool the microclimate more than others); suppression of major coffee pest-Xylosandrus compactus (some trees are associated with the pest); weeds suppression (some trees suppress weed growth); fuel wood provision (some trees provide better firewood); tree growth rate (some trees grow faster) and timber provision (some trees provide better timber). Each farmer ranked these ES according to importance to his/her livelihood needs. Second, we presented each farmer with technical sheets (visual aided tree representations for all tree species) of the 20 most abundant trees in his/her respective rainfall zone; and asked him/her to select 10 tree species that he/ she knew best. Each farmer ranked his/her selected 10 trees in order of suitability for providing each of the 12 ES. The ranking was visually aided by technical sheets (as a representation of tree species) that farmers arranged from most to the least suitable tree for providing an ES: ranking one ES at a time until farmers completed ranking trees for all the 12 ES (Elliott 2009).

Data analysis

Tree species richness and abundance among rainfall zones

To determine tree species richness among rainfall zones, we analyzed tree inventory data using Estimate S software version 9 (Colwell 2013). We present the four (Chao 1, Chao 2, Jack 1 and Jack 2) most precise, accurate, robust and unbiased species richness estimators (Walther and Moore 2005; Chiarucci 2012). To compare species richness among rainfall zones, we used species accumulation curves scaled by individuals (Chazdon et al. 1998; Gotelli and Colwell 2001) 
and extrapolated with 95\% confidence boundaries (Shen et al. 2003) until the most species-rich sample reached an asymptote (Colwell et al. 2012). Species richness is significantly different between zones if respective confidence boundaries at asymptote do not inter-cross each other. To determine species similarity among rainfall zones, we used Bray-Curtis (BC) abundance-based similarity index (Bray and Curtis 1957). BC index value ranges from zero (perfectly similar) to one (perfectly dissimilar). We used rank abundance curves to determine the most abundant set (20 species) of trees in each rainfall zone that represented over $90 \%$ of tree diversity.

\section{Farmers' local knowledge of coffee-shade trees}

We analyzed farmers' ranking of (i) ES and (ii) trees for providing ES at plot level; using Bradley and Terry (BT) model (Bradley and Terry 1952) in 'BradleyTerry2' package of $\mathrm{R}$ (Turner and Firth 2012; R Core Team 2015). The model based on how various farmers ranked trees for ES provision to generate a score upon which it ranks the trees. The scores are, however, not absolute and are only meaningful relative to one another and can take on any value from negative to positive infinity but the magnitude between score is absolute and does not change. To simplify comparisons, we shifted/transformed results to get the lowest score to zero so as to yield positive scores only. The difference between scores of individual trees determines the probability of ranking one tree above another in the final output. BradleyTerry model also produces a confidence interval for each score that reflects the ranking frequency of that tree. Larger confidence intervals show trees selected rarely for ranking and ranked less concordantly. The model output is a graph showing the final rank order of tree species and associated confidence interval based on model-generated scores. The rank order shows farmers' ranking of how suitably trees deliver ES at the plot level, i.e., from the most to the least suitable tree for a particular ES. To allow flexibility and avoid recommending only one tree per ES; we applied a set of rules to determine the best (top) performing group of trees for each ES:

i. The top group should have at least four tree species.

ii. If the lower boundary of the confidence interval of current ranked item is lower than the score of the next ranked item, then those items belong to the same group. If the lower boundary of the confidence interval of the current ranked item is higher than the score of the next ranked item then such items belong to different groups.

iii. If the tree right next to the topmost group is a lone group member (occurs alone in its group), it is adjoined to the topmost group. The most suitable (top) groups of trees for various ES are herein referred to as the ES groups of trees.

Relating diversity rank to 'Needs rank' of ecosystem service groups

'Diversity rank' here means the ordering of ecosystem-service groups of trees from one with highest tree diversity to one with lowest tree diversity. To order ES groups according to diversity, we used a Rényi diversity profile (Rényi 1961; Tóthmérész 1995; Lövei et al. 2013). Renyi diversity profile values were calculated in $\mathrm{R}$ statistical software ( $\mathrm{R}$ Core Team 2015) with package Biodiversity R (Kindt et al. 2015). If the profile of group A is above the profile of group B at all Renyi values, then group $A$ is more diverse than group B. If the profile of group A inter-crosses that of group B, the two groups cannot be ordered (Kindt et al. 2006). In this case, we revert to the less strict approach of a single diversity index, Shannon diversity index, to derive the 'Diversity rank'. We derived Shannon diversity index from, and when the Renyi value approaches one (Kindt et al. 2006). The 'Needs rank' means the ordering of ES groups from most to least important as ranked by farmers and analyzed using BT model. We examined the correlation between 'Diversity rank' and "Needs rank" using Spearman's rank correlation test (Höft et al. 1999).

\section{Results}

Tree species composition and diversity

The study recorded 1604 trees in low rainfall zone, 2196 trees from moderate rainfall zone and 2009 trees in high rainfall zone. Tree-species richness ranged from 29 species ha ${ }^{-1}$ in low rainfall zone to 39 species $\mathrm{ha}^{-1}$ in high rainfall zone (Table 1). The low rainfall 
Table 1 Species richness for the three rainfall zones of Central Uganda, based on four non-parametric species richness estimators and their standard errors in parentheses

\begin{tabular}{llllllrll}
\hline Rainfall zone & Trees & Genera & Families & Species ha & Chao 1 & Chao 2 & Jack 1 & Jack 2 \\
\hline High & 2009 & 42 & 28 & 39 & $46.51(2.13)$ & $49.92(4.76)$ & $51.98(3.18)$ & $54.17(6.64)$ \\
Moderate & 2196 & 35 & 24 & 35 & $42(0.12)$ & $42(0.08)$ & $42.98(0.98)$ & $39.21(0.00)$ \\
Low & 1604 & 37 & 20 & 29 & $36.11(1.5)$ & $36.93(2.22)$ & $38.74(1.98)$ & $39.06(4.17)$ \\
\hline
\end{tabular}

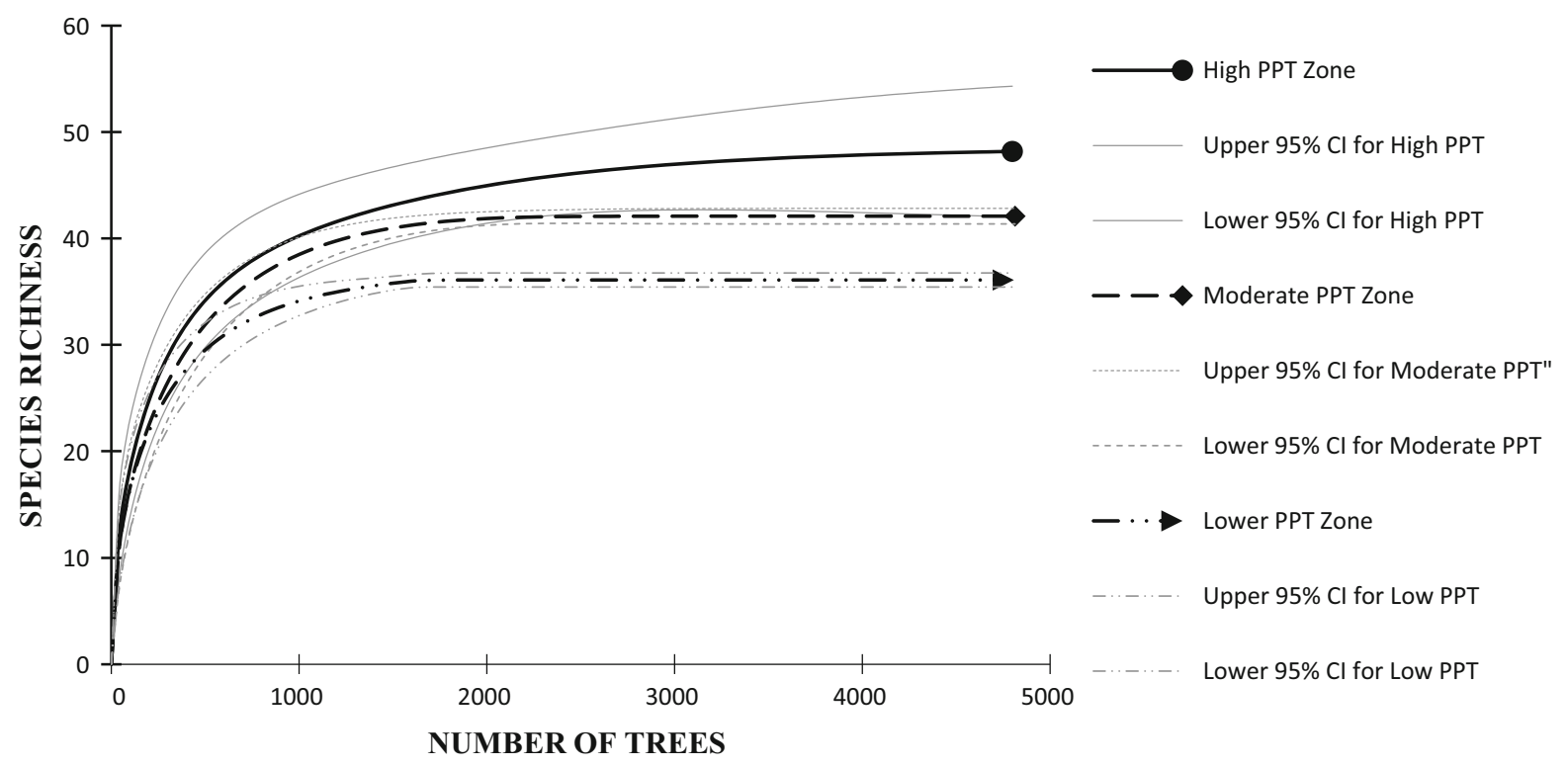

Fig. 2 Species accumulation curves and associated bootstrap confidence boundaries for the three rainfall zones. If the lines showing confidence boundaries for different rainfall zones cross

zone had the lowest number of tree species, genera and families while high rainfall zone had the highest number of tree species, genera and families (Table 1). Species richness varied among rainfall zones in a pattern similar to that of taxonomic groups (Fig. 2). There was low species similarity among rainfall zones but low and high rainfall zones showed higher similarity $(\mathrm{BC}=0.670)$ than between moderate and low ones $(\mathrm{BC}=0.685)$ and between high and moderate rainfall zones $(\mathrm{BC}=0.812)$. In each rainfall zone, about the top 20 tree species constituted about $90 \%$ of total tree abundance (Fig. 3).Consequently, only the most abundant 20 species were used in the ranking exercise for each rainfall zone. each other, species richness in the two rainfall zones is not significantly different $($ PPT zone $=$ rainfall zone $)$

Farmers' local knowledge of trees and ecosystem services

Farmers ranked 12 ES according to their farm and livelihood needs in each rainfall zone (Fig. 4). Generally, the importance of tree-ecosystem services to farmers differed among rainfall zones. For instance, the importance of shade quality and leaf litter provision increase but the need to suppress black coffee twig borer reduces from high to low rainfall zones. However, some ES were equally important in all rainfall zones. For example, farmers ranked soil moisture preservation and yield increase in the top three ES in all rainfall zones. For every ES considered, we determined a group of trees that farmers think that are the best at providing that service (Table 2). For example, Fig. 5 shows the ranking of trees suitable for 
Fig. 3 Rank abundance curves of agroforestry tree species in Luweero. Each line represents one rainfall (precipitation) zone. Tree ranking order is based on abundance. From most to least abundant tree

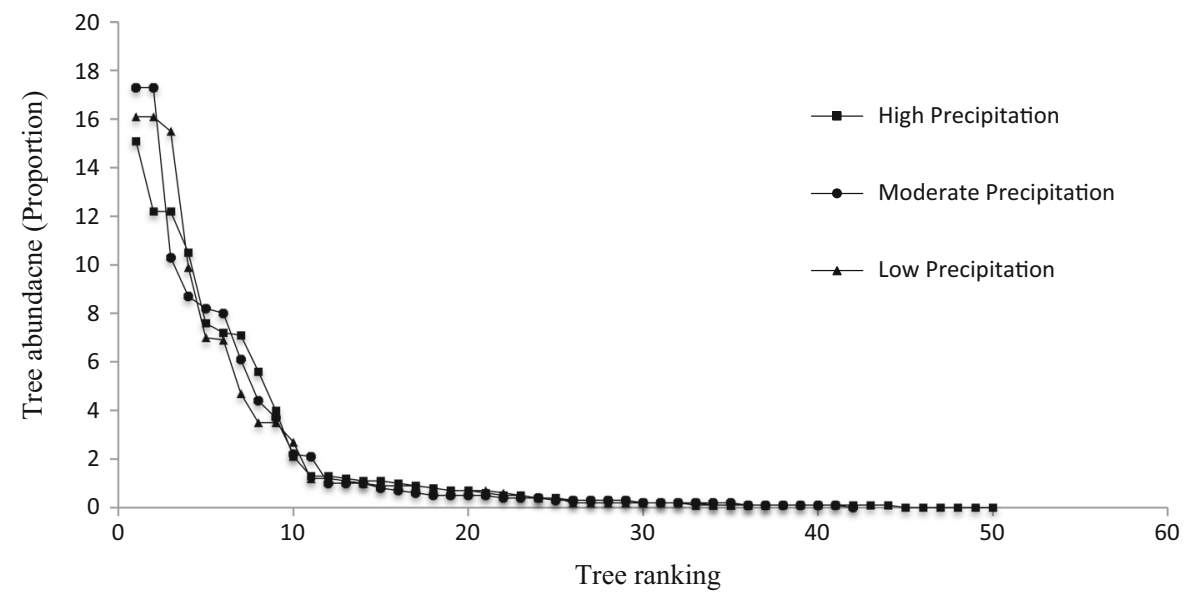



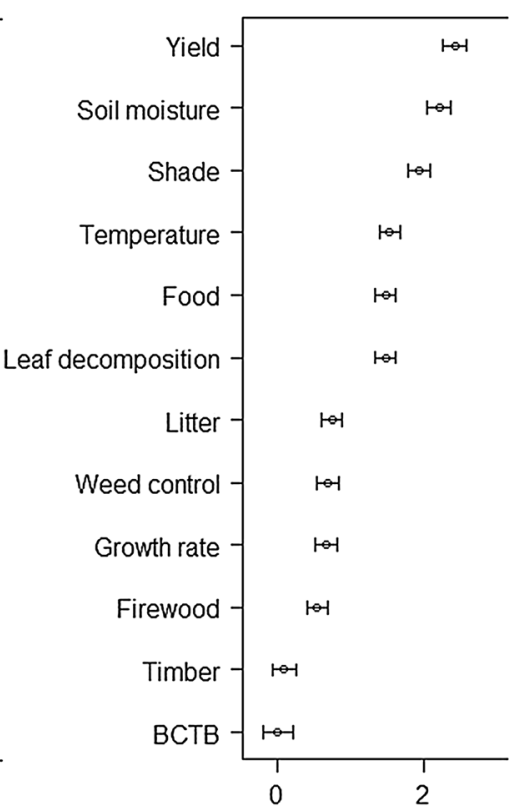

Fig. 4 Farmers' ranking of the priority ecosystems services provided by trees on coffee farms according to order of importance in different rainfall zones, i.e., Needs rank for each rainfall zone. From left to right: high, moderate and low rainfall zones

shade quality for coffee and the most suitable tree species (top group) are marked with a rectangle. According to farmers' knowledge, this top group forms the ES group of tree species for shade quality in high rainfall zone. Trees were also not limited to serving one ES. According to farmers, the most multipurpose trees were: Albizia coriaria Oliv, Fabaceae family, suitable for 9 out of 12 ES in all rainfall zones and Ficus natalensis Hochstetter, Moraceae family, suitable for 8 out of 12 ES in all rainfall zones. The least multipurpose trees were
Annona muricata, Annonaceae family, and Grevillea robusta, Proteaceae family, as they each served only one ES in one rainfall zone but ranked highly for the respective ES they served.

Relating on-farm tree diversity to farmers need for ecosystem services

This study determined farmers' ranking of ES (Needs rank) from most to least important for their livelihoods (Fig. 4) across rainfall zones. The study also used tree 


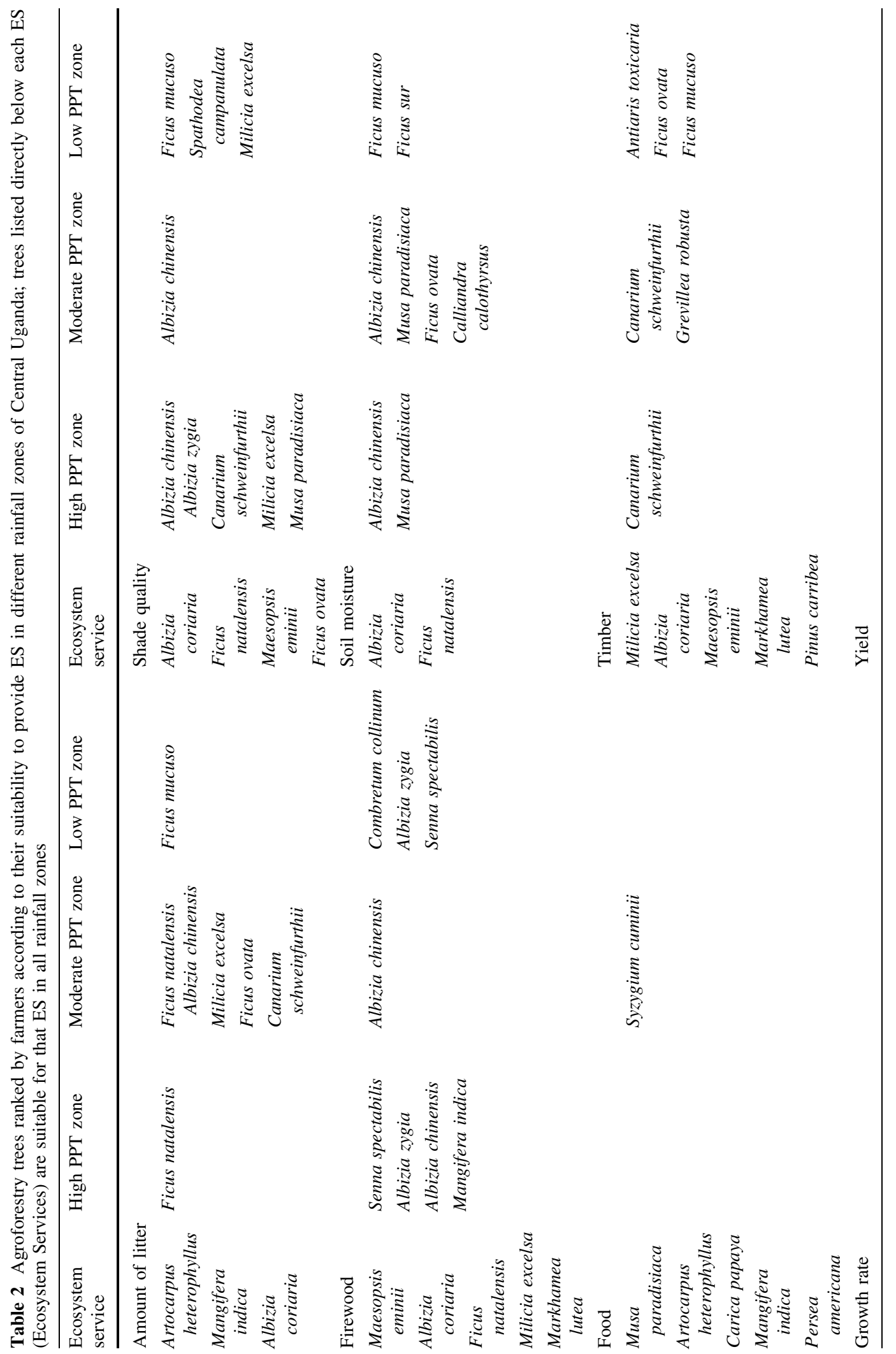




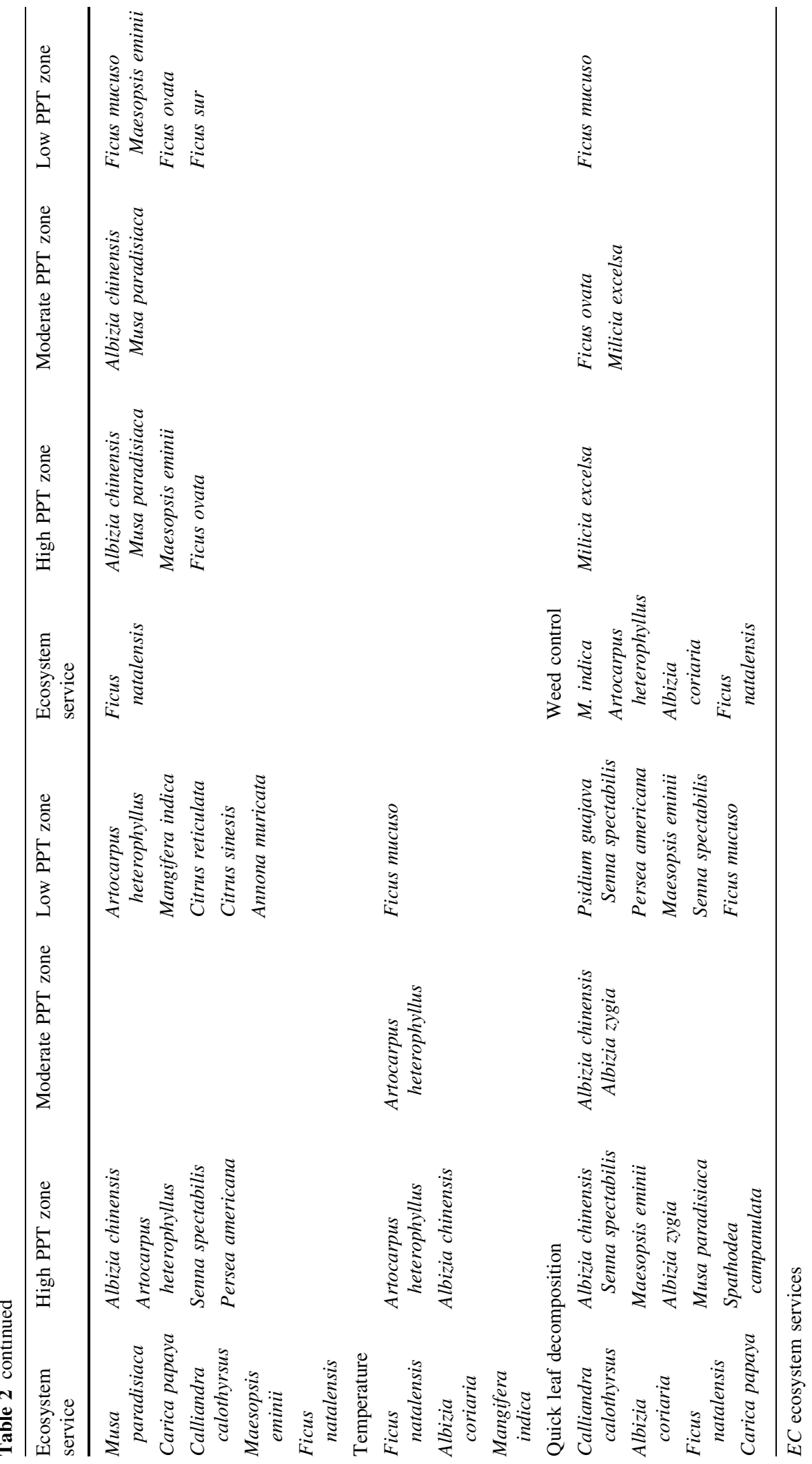


Fig. 5 Ranking of agroforestry tree species for the provision of quality shade for coffee in the high rainfall zone. (The rectangular marking highlights the most suitable trees for shading coffee in the high rainfall zone, i.e., ecosystem service group of trees)

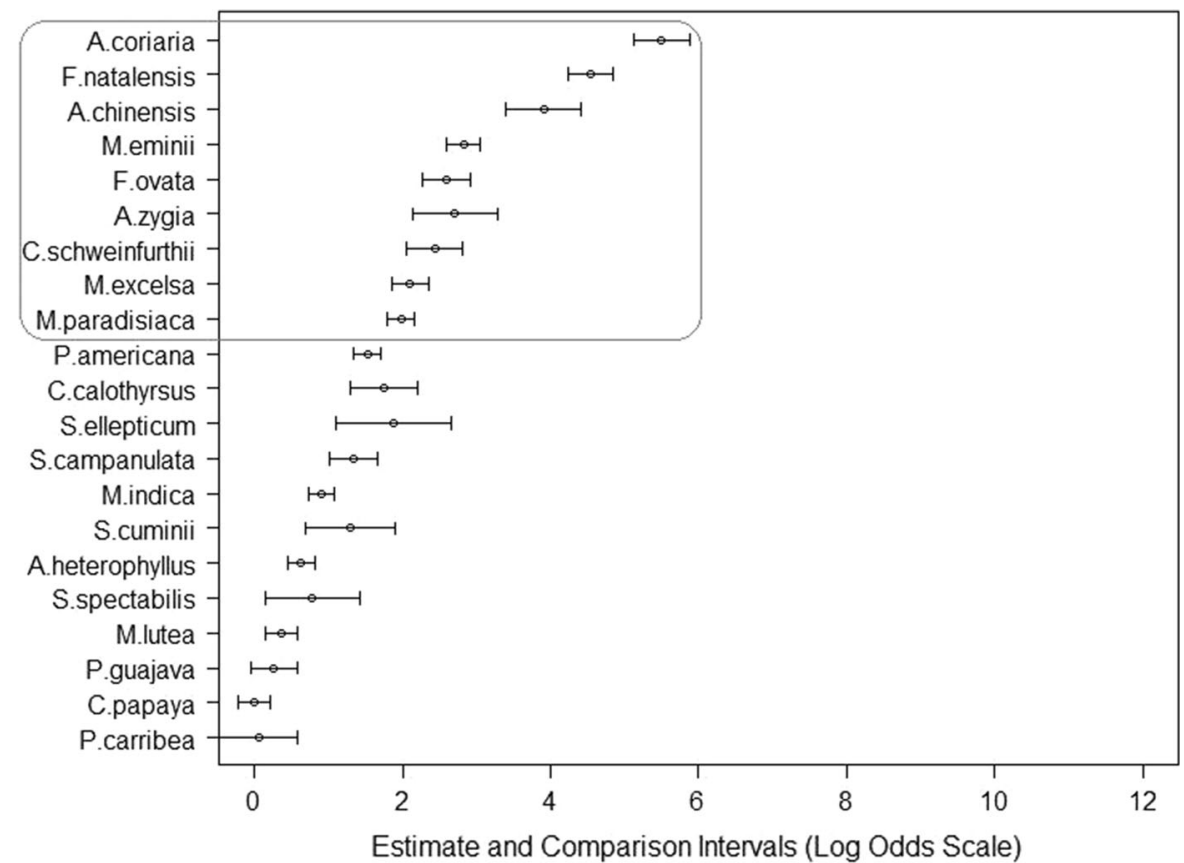

diversity (Diversity rank) to order ES groups from most to least diverse in each rainfall zone (Fig. 6; Table 3). We found that 'Diversity rank' was not significantly correlated with 'Needs rank' in any rainfall zones (Fig. 7): on-farm tree diversity of ES groups did not match farmers need for such ES.

\section{Discussion}

Tree species composition and diversity

Most tree-diversity studies in agroforestry consider intensification gradients especially with increasing distance from natural forests but this study considered agroforests far from natural forests (no nearby forest) but along a rainfall gradient (Méndez et al. 2007; Valencia et al. 2014; Häger et al. 2015). We found relatively few species, genera, and families per unit area. This is due to the fact that, without a nearby natural forest, farmers entirely rely on and overexploit agroforests and yet re-plant little beyond harnessing natural regeneration (Häger et al. 2015). Low species richness means low functional redundancy implying that minimal losses in species richness will adversely affect ecosystem functioning (Barnes et al. 2014). Along the rainfall gradient, we found higher species richness in high rainfall zone than in low rainfall zone and species similarity was low among rainfall zones. This is because different rainfall zones support natural regeneration differently which emphasizes the need for deliberate enrichment planting to boost species restocking especially in low rainfall zone where natural regeneration of some trees prioritized by farmers may not be as quick as farmers would like it to be (Busby et al. 2010). Increasing species richness will increase ecosystem functioning, functional redundancy, and stability of ES delivery (Gamfeldt et al. 2013; de Beenhouwer et al. 2013; Barnes et al. 2014; Caudill et al. 2014). However, we want to emphasize that increases in tree diversity may not necessarily increase ecosystem functioning unless these increases target tree species suitable for prioritized ES (Radchuk et al. 2015).

Farmers' local knowledge of trees and the ecosystem services they deliver

Generally ecological conditions, like rainfall, influence tree distribution in coffee agroforestry (Bisseleua et al. 2013). Our findings emphasize this consensus and further demonstrate that relative suitability of trees to deliver ES changes among rainfall zones. For example, diversity data showed that Ficus mucuso 
Fig. 6 Renyi diversity profiles of ecosystem service groups of trees in three rainfall zones of Central Uganda (ecosystem service group of trees is constituted of trees suitable for providing a particular ecosystem service)
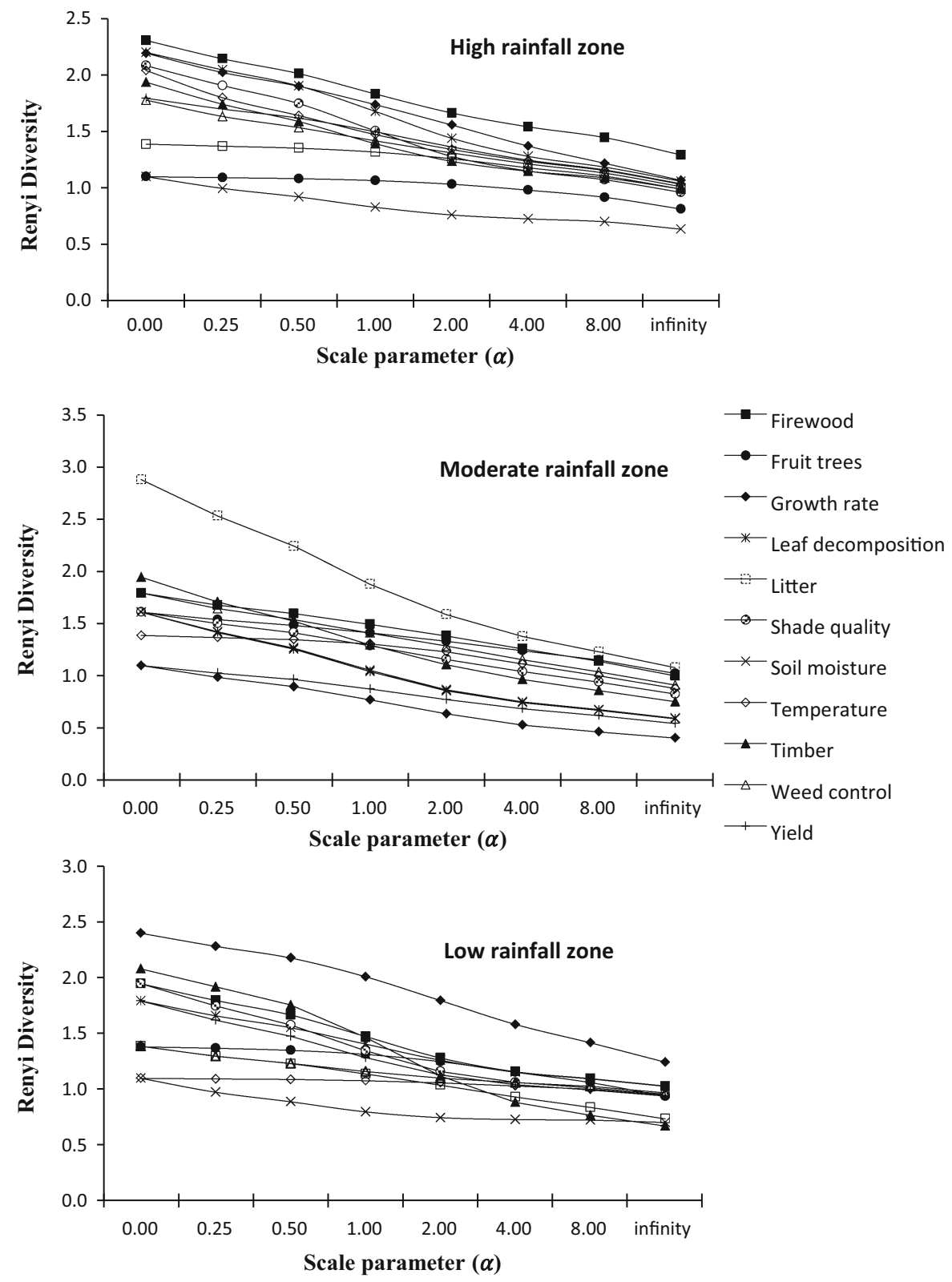

grows in all rainfall zones but only farmers of low rainfall zone ranked it highly among trees suitable for shade quality. Its shade quality is due to its large canopy, but in non-limiting water conditions of high rainfall zone, farmers prefer other tree species such as Albizia chinensis that provides better quality shade to coffee even though it needs more water. Furthermore, relative importance of ES changes with rainfall zones. Relative importance of shade and leaf litter increased from high to low rainfall zone. This is because the low rainfall zone is hotter and coffee needs higher shade level than coffee in high rainfall zone (DaMatta et al. 2007). Farmers also value trees with a lot of leaf litter; an attribute of trees key in nutrient recycling (Dhanya et al. 2013). Therefore, each ecological zone is unique and needs its own tree composition to deliver farmers' prioritized ES.

Past research efforts looked at the provision of ES without jeopardizing yield (de Beenhouwer et al. 2013; Lescourret et al. 2015). This study however 
Table 3 Shannon diversity index $(\mathrm{H})$, diversity rank and needs rank of studied ecosystem services in three rainfall zones of Central Uganda

\begin{tabular}{|c|c|c|c|c|c|c|c|c|c|}
\hline \multirow[t]{2}{*}{ Ecosystem services } & \multicolumn{3}{|c|}{ High rainfall zone } & \multicolumn{3}{|c|}{ Moderate rainfall zone } & \multicolumn{3}{|c|}{ Low rainfall zone } \\
\hline & $\mathrm{H}$ & $\begin{array}{l}\text { Diversity } \\
\text { rank }^{\mathrm{a}}\end{array}$ & $\begin{array}{l}\text { Needs } \\
\text { rank }^{\mathrm{b}}\end{array}$ & $\mathrm{H}$ & $\begin{array}{l}\text { Diversity } \\
\text { rank }^{\mathrm{a}}\end{array}$ & $\begin{array}{l}\text { Needs } \\
\text { rank }^{\mathrm{b}}\end{array}$ & $\mathrm{H}$ & $\begin{array}{l}\text { Diversity } \\
\text { rank }^{\mathrm{a}}\end{array}$ & $\begin{array}{l}\text { Needs } \\
\text { rank }^{\mathrm{b}}\end{array}$ \\
\hline Litter & 0.32 & 11 & 11 & 1.88 & 1 & 8 & 1.28 & 7 & 7 \\
\hline Soil moisture & 0.83 & 10 & 2 & 1.05 & 8 & 1 & 1.31 & 6 & 2 \\
\hline Food & 1.06 & 9 & 4 & 1.41 & 3 & 5 & 1.41 & 4 & 5 \\
\hline Timber & 1.39 & 8 & 10 & 1.30 & 6 & 11 & 1.16 & 8 & 11 \\
\hline Weed Control & 1.42 & 7 & 9 & 1.41 & 4 & 7 & 1.47 & 3 & 8 \\
\hline Temperature & 1.47 & 6 & 6 & 1.31 & 5 & 6 & 1.35 & 5 & 4 \\
\hline Yield & 1.50 & 5 & 1 & 0.88 & 10 & 3 & 1.47 & 2 & 1 \\
\hline Shade quality & 1.50 & 4 & 5 & 1.29 & 7 & 4 & 1.14 & 9 & 3 \\
\hline $\begin{array}{l}\text { Leaf } \\
\text { decomposition }\end{array}$ & 1.68 & 3 & 3 & 1.04 & 9 & 2 & 2.01 & 1 & 6 \\
\hline Growth rate & 1.74 & 2 & 8 & 0.77 & 11 & 9 & 1.08 & 10 & 9 \\
\hline Firewood & 1.83 & 1 & 7 & 1.49 & 2 & 10 & 0.80 & 11 & 10 \\
\hline
\end{tabular}

${ }^{\mathrm{a}}$ Rank of ecosystem service groups of trees according to their tree diversity

${ }^{\mathrm{b}}$ Rank of ecosystem services in order of importance to farmers livelihoods

considered yield increase as one of the many ES rather than one to trade-off with other ES. Farmers' knowledge showed that specific trees suited better than others certain ES. Therefore, we grouped trees according to how well they serve particular ES. Our groupings are consistent with results from previous related studies. For example, our results agree with those of Omeli (2011) showing that leaves from Ficus natalensis, Carica papaya and Albizia coriaria decompose quickly and hence such trees are therefore good for nutrient recycling. Our results also agree with Jagoret et al. (2014) identifying Milicia excelsa, A. coriaria and Markhamia lutea as good timber trees, and those of Kalanzi and Nansereko (2014) showing that M. excelsa and Ficus mucuso improve soil fertility.

Relating on-farm diversity to farmers' need of ecosystem services

Recognition of farmers' needs and priorities in conservation is gaining adhesion (Harvey et al. 2008; Garcia et al. 2010). We advance the consensus by testing for correlation between farmers' needs (Needs rank) and their on-farm tree diversity (Diversity rank). Farmers' needs did not correlate with on- farm tree diversity (Fig. 7). Although tree-utility influences tree planting (Valencia et al. 2014; Häger et al. 2015), farmers did not necessarily maintain higher diversity in ES groups of higher priority to them. For example, soil moisture preservation ranked highly among farmers' priority ES but the on-farm diversity of the ES group for 'soil moisture preservation' was low. According to the insurance hypothesis (Leary and Petchey 2009; Mori et al. 2013), ES groups with lower tree diversity are less ecologically stable and render farmers less resilient to challenges like climate change (Tscharntke et al. 2011). Therefore, we emphasize that farmers should base tree diversification on tree-suitability for ES (Fig. 8), particularly for adapting to climate change (Minang et al. 2014).

'FaD-FaN' approach: matching farm tree diversity to farmers' needs

Analysis of previous agroforestry research revealed some research questions that remain unanswered (Mbow et al. 2014b) such as: which tree species suite which site conditions? How can we optimize ES delivery through agroforestry systems? We propose that desired ES can be delivered through optimizing on 
farm tree-composition with respect to the suitability of various trees to deliver ES in different environments. This can be achieved through a step-wise approach we refer to as FaD-FaN-farm tree diversity to farmers' needs at the plot level. The premise of $\mathrm{FaD}-\mathrm{FaN}$ is that we assessed on-farm tree diversity on one side and farmer's needs (ES) on the other side. Then we examined whether a particular farmer has the trees that are suitable for providing his/her prioritized ES. If not, then the farmer is advised to adjust his on-farm tree composition to add/increase on trees species suitable for his/her prioritized ES.

In our study, on-farm tree diversity did not match farmers' need of ES farmers and we recommend increasing on-farm tree Diversity $(\mathrm{FaD})$ to match Farmer's Needs (FaN). The diversity increase could be either species richness or abundance or both. However, the trees to add must be chosen for suitability to provide prioritized ES that has fewer trees on the farm. The FaD-FaN approach, therefore, supports integrating farmers' needs and priorities in agroforestry designs thereby answering numerous calls for such integration (Harvey et al. 2008; Garcia et al. 2010; Schroth and McNeely 2011; Rey Benayas
Fig. 8 A conceptual framework of the 'FaD-FaN' (matching farm diversity to farmers' needs) approach for optimizing coffee-agroforestry tree composition for ecosystem service delivery

and Bullock 2012). FaD-FaN approach is also a practical instrument for participatory engagement of farmers and scientists to design conservation and agroforestry programs (Lescourret et al. 2015). The implementation of the approach may be aided by a decision support tool (van der Wolf et al. 2016).

\section{Conclusions and recommendations}

In the present study, changes in rainfall zones influenced tree diversity, the relative importance of ES and relative tree-suitability for ES delivery indicating that local context underpins appropriate agroforestry designs. Therefore, the FaD-FaN approach advocates for determining tree diversity, the relative importance of ES and relative tree-suitability for ES delivery in each rainfall zone separately. In farms where tree diversity does not match farmers'
Fig. 7 Correlations between 'Diversity rank' and 'Needs rank' for the three rainfall zones and the ideal situation showing Spearman's rho and $\mathrm{p}$ value for each. Asterisk indicate correlation is not significant, Diversity rank rank of ecosystem service groups of trees according to their tree diversity, Needs rank rank of ecosystem services in order of importance to farmers' livelihoods, ecosystem service group of trees is constituted of trees suitable for providing that ecosystem service
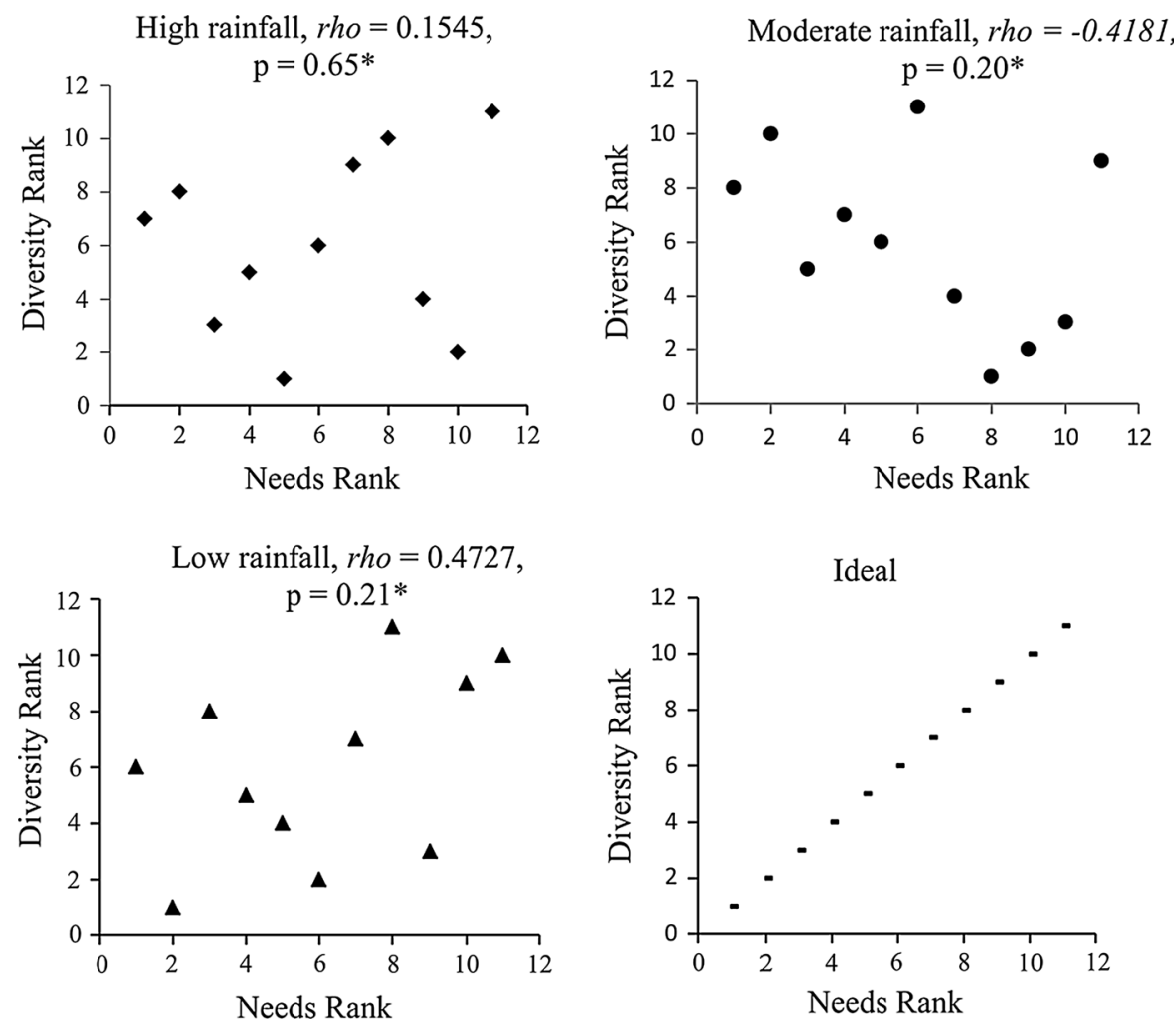
Matching Farm tree DIVERSITY to Farmers' NEEDS (FaD-FaN) approach

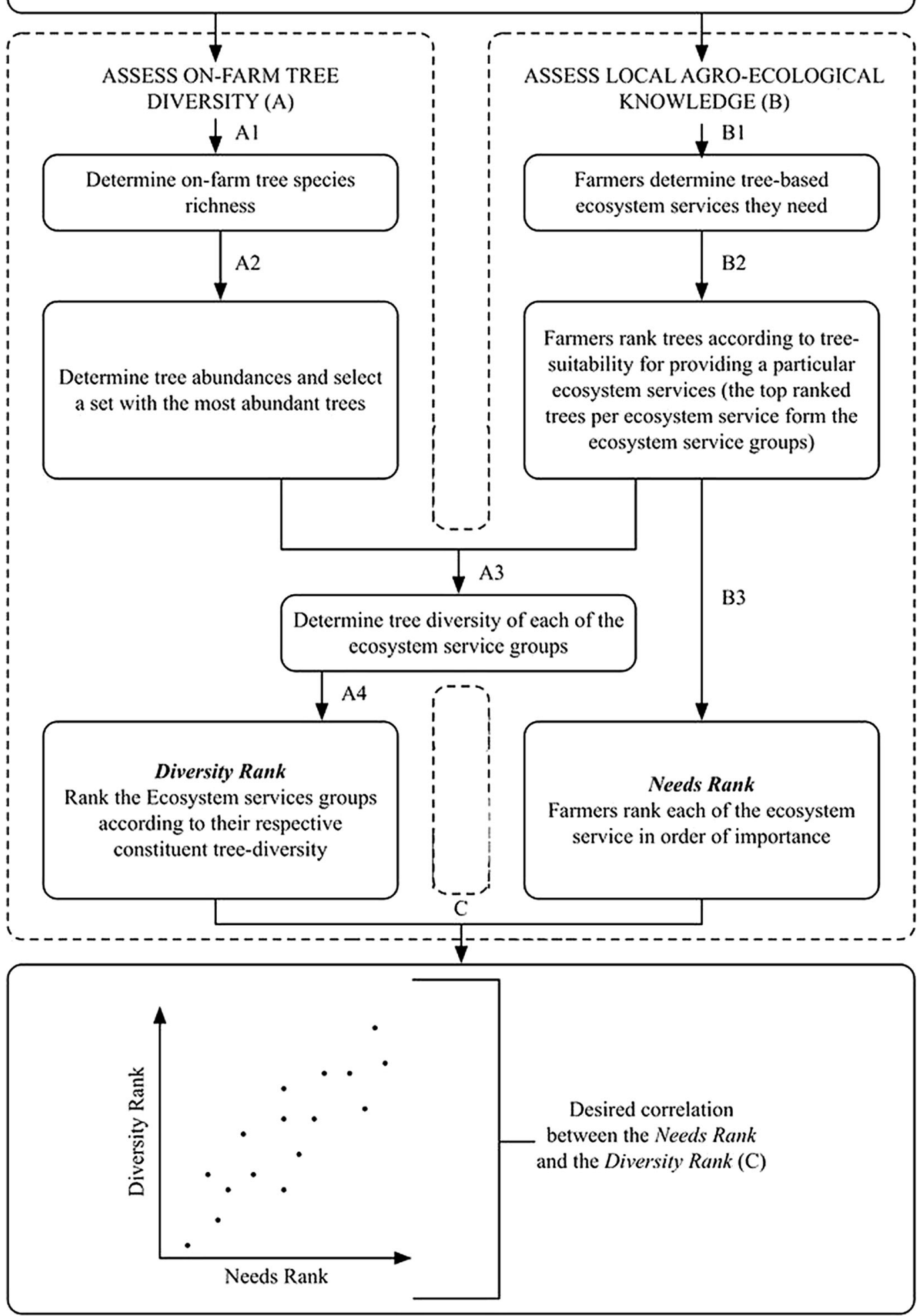


prioritized needs, we propose deliberate increases in on-farm tree diversity targeted to boost prioritized ES of currently low tree diversity-cold spot approach (Melián et al. 2015). It is also critical to scale out the development of 'ES groups' of trees to other landscapes and socio-economic conditions. These ES groups of trees will underpin tree selection basing on tree suitability for ES.

In this study, farmers' needs for ES did not match with their on-farm tree diversity; there is need to promote a tree management approach that supports tree diversification with respect to tree suitability for ES-the FaD-FaN approach. To simplify the task of implementing the FaD-FaN approach especially for multiple ES, van der Wolf et al. (2016) presented a decision support tool. Farmers select ES that they need and the tool outputs a set composed of the best-suited tree species at the plot level. Farmers can now optimize their on-farm tree composition for ES delivery in coffee agroforestry. By adopting the $\mathrm{FaD}-\mathrm{FaN}$ in coffee growing regions beyond the study area, agroforestry will be a step closer to delivering on the promise of improving agricultural livelihoods.

Acknowledgements This research was conducted under CGIAR Research Programs on Climate Change Agriculture and Food Security (CCAFS) and Forests, Trees and Agroforestry (FTA). It was supported by USAID and Hanns R Neumann Stiftung. We also thank D. Mukasa, O. Giller, D. Senyonjo, J. van der Wolf, G. Gram, R. Coe, G. Kagezi, A. Mawanda and A. Kehbila for their valuable contributions at different stages of this research.

Open Access This article is distributed under the terms of the Creative Commons Attribution 4.0 International License (http:// creativecommons.org/licenses/by/4.0/), which permits unrestricted use, distribution, and reproduction in any medium, provided you give appropriate credit to the original author(s) and the source, provide a link to the Creative Commons license, and indicate if changes were made.

\section{References}

Adhikari U, Nejadhashemi AP, Woznicki SA (2015) Climate change and eastern Africa: a review of impact on major crops. Food Energy Secur 4:110-132. https://doi.org/10. 1002/fes3.61

Barnes AD, Jochum M, Mumme S et al (2014) Consequences of tropical land use for multitrophic biodiversity and ecosystem functioning. Nat Commun 5:1-7. https://doi. org/10.1038/ncomms6351
Bisseleua HBD, Fotio D, Yede ADM et al (2013) Shade tree diversity, cocoa pest damage, yield compensating inputs and farmers' net returns in West Africa. PLoS ONE 8:56115. https://doi.org/10.1371/journal.pone.0056115

Bradley RA, Terry ME (1952) Rank analysis of incomplete block designs: I. The method of paired comparisons on JSTOR. In: Biometrika. http://www.jstor.org/stable/233 4029? origin=crossref\&seq=1\#page_scan_tab_contents. Accessed 18 Jun 2015

Bray JR, Curtis JT (1957) An Ordination of the upland forest communities of Southern Wisconsin. Ecol Monogr 27:325-349. https://doi.org/10.2307/1942268

Bunn C, Läderach P, Ovalle Rivera O, Kirschke D (2015) A bitter cup: climate change profile of global production of Arabica and Robusta coffee. Clim Change 129:89-101. https://doi.org/10.1007/s10584-014-1306-X

Busby PE, Vitousek P, Dirzo R (2010) Prevalence of tree regeneration by sprouting and seeding along a rainfall gradient in Hawai'i. Biotropica 42:80-86. https://doi.org/ 10.1111/j.1744-7429.2009.00540.x

Cardinale BJ, Matulich KL, Hooper DU et al (2011) The functional role of producer diversity in ecosystems. Am J Bot 98:572-592. https://doi.org/10.3732/ajb.1000364

Cardinale BJ, Duffy JE, Gonzalez A et al (2012) Corrigendum: biodiversity loss and its impact on humanity. Nature 489:326. https://doi.org/10.1038/nature11373

Caudill SA, Vaast P, Husband TP (2014) Assessment of small mammal diversity in coffee agroforestry in the Western Ghats, India. Agrofor Syst 88:173-186. https://doi.org/10. 1007/s10457-013-9664-3

Chazdon R, Colwell R, Denslow J, Guariguata M (1998) Statistical methods for estimating species richness of woody regeneration in primary and secondary rain forests of northeastern Costa Rica. In: Dallmeier F, Comiskey JA (eds) Man and biosphere series. UNESCO and The Parthenon Publishing Group, Paris, pp 285-309

Chiarucci A (2012) Estimating species richness: still a long way off! J Veg Sci 23:1003-1005. https://doi.org/10.1111/jvs. 12003

Coe R, Sinclair F, Barrios E (2014) Scaling up agroforestry requires research "in" rather than "for" development. Curr Opin Environ Sustain 6:73-77. https://doi.org/10.1016/j. cosust.2013.10.013

Colwell RK (2013) EstimateS: statistical estimation of species richness and shared species from samples. Version 9. User's guide and application. In: Estim. S. http://viceroy. eeb.uconn.edu/estimates/. Accessed 9 Jun 2015

Colwell RK, Chao A, Gotelli NJ et al (2012) Models and estimators linking individual-based and sample-based rarefaction, extrapolation and comparison of assemblages. J Plant Ecol 5:3-21. https://doi.org/10.1093/jpe/rtr044

DaMatta FF, Ronchi CP, Maestri M, Barros RS (2007) Ecophysiology of coffee growth and production. Braz J Plant Physiol 19:485-510

de Beenhouwer M, Aerts R, Honnay O (2013) A global metaanalysis of the biodiversity and ecosystem service benefits of coffee and cacao agroforestry. Agric Ecosyst Environ 175:1-7. https://doi.org/10.1016/j.agee.2013.05.003

Dhanya B, Viswanath S, Purushothaman S (2013) Does litterfall from native trees support rainfed agriculture? Analysis of Ficus trees in agroforestry systems of southern dry 
agroclimatic zone of Karnataka, southern India. J Forest Res 24:333. https://doi.org/10.1007/s11676-013-0357-6

Elliott LC (2009) Farmers' perceptions about the utilities of trees associated with coffee farms in central province. Bangor University, Kenya

Funk C, Rowland J, Eilerts G, White L (2012) A climate trend analysis of Uganda. Kampala

Gamfeldt L, Snäll T, Bagchi R et al (2013) Higher levels of multiple ecosystem services are found in forests with more tree species. Nat Commun 4:1340. https://doi.org/10.1038/ ncomms 2328

Garcia CA, Bhagwat SA, Ghazoul J et al (2010) Biodiversity conservation in agricultural landscapes: challenges and opportunities of coffee agroforests in the Western Ghats, India. Conserv Biol 24:479-488. https://doi.org/10.1111/j. 1523-1739.2009.01386.x

Gotelli NJ, Colwell RK (2001) Quantifying biodiversity: procedures and pitfalls in the measurement and comparison of species richness. Ecol Lett 4:379-391. https://doi.org/10. 1046/j.1461-0248.2001.00230.x

Häger A, Fernández Otárola M, Stuhlmacher MF et al (2015) Effects of management and landscape composition on the diversity and structure of tree species assemblages in coffee agroforests. Agric Ecosyst Environ 199:43-51. https:// doi.org/10.1016/j.agee.2014.08.022

Harvey CA, Komar O, Chazdon R et al (2008) Integrating agricultural landscapes with biodiversity conservation in the Mesoamerican hotspot. Conserv Biol 22:8-15. https:// doi.org/10.1111/j.1523-1739.2007.00863.x

Höft M, Barik S. K, Lykke AM (1999) Quantitative ethnobotany: applications of multivariate and statistical analyses in ethnobotany. In: People and Plants Working Paper, Vol. 6

IPCC (2014) Climate change 2014: impacts, adaptation and vulnerability. Cambridge University Press, Cambridge

Jagoret P, Kwesseu J, Messie C et al (2014) Farmers' assessment of the use value of agrobiodiversity in complex cocoa agroforestry systems in central Cameroon. Agrofor Syst 20:983-1000

Kalanzi F, Nansereko S (2014) Exploration of farmers' tree species selection for coffee agroforestry in Bukomansimbi district of Uganda. Int J Res Land-use Sustain 1:9-16

Katende AB, Birnie A, Tengnas B (1995) Useful Trees and Shrubs for Uganda, 1st Editio. Regional Land Management Unit, RELMA/Sida, Nairobi

Kindt R, Coe R (2015) Tree diversity analysis. A manual and software for common statistical methods for ecological and biodiversity studies. World Agroforestry Centre (ICRAF), Nairobi

Kindt R, Van Damme P, Simons AJ (2006) Tree diversity in Western Kenya: using profiles to characterise richness and evenness. Biodivers Conserv 15:1253-1270. https://doi. org/10.1007/s10531-005-0772-x

Leary DJ, Petchey OL (2009) Testing a biological mechanism of the insurance hypothesis in experimental aquatic communities. J Anim Ecol 78:1143-1151. https://doi.org/10.1111/ j.1365-2656.2009.01586.x

Lescourret F, Magda D, Richard G et al (2015) A social-ecological approach to managing multiple agro-ecosystem services. Curr Opin Environ Sustain 14:68-75. https://doi. org/10.1016/j.cosust.2015.04.001
Lövei G, Liu W, Guo J, Wan F-H (2013) The use of the Rényi scalable diversity index to assess diversity trends in comparative and monitoring studies of effects of transgenic crops. J Biosaf 22:43-50

Lwasa J, Isabirye B, Okecha J, Biruma M (2011) Integrating NARO's and other agricultural information systems into an early warning system (EWS) for climate change adaptation and effects mitigation. Kampala

Mbow C, Van Noordwijk M, Luedeling E et al (2014a) Agroforestry solutions to address food security and climate change challenges in Africa. Curr Opin Environ Sustain 6:61-67. https://doi.org/10.1016/j.cosust.2013.10.014

Mbow C, van Noordwijk M, Prabhu R, Simons T (2014b) Knowledge gaps and research needs concerning agroforestry's contribution to sustainable development goals in Africa. Curr Opin Environ Sustain 6:162-170. https://doi. org/10.1016/j.cosust.2013.11.030

Melián CJ, Seehausen O, Eguíluz VM et al (2015) Diversification and biodiversity dynamics of hot and cold spots. Ecography (Cop) 38:393-401. https://doi.org/10.1111/ ecog.01162

Méndez EV, Gliessman SR, Gilbert GS (2007) Tree biodiversity in farmer cooperatives of a shade coffee landscape in western El Salvador. Agric Ecosyst Environ 119:145-159. https://doi.org/10.1016/j.agee.2006.07.004

Minang PA, Duguma LA, Bernard F et al (2014) Prospects for agroforestry in REDD + landscapes in Africa. Curr Opin Environ Sustain 6:78-82. https://doi.org/10.1016/j.cosust. 2013.10.015

Mori AS, Spies TA, Sudmeier-Rieux K, Andrade A (2013) Reframing ecosystem management in the era of climate change: issues and knowledge from forests. Biol Conserv 165:115-127. https://doi.org/10.1016/j.biocon.2013.05. 020

Omeli MRW (2011) Tree attribute ranking and phenology study: farmers' knowledge of trees commonly found on coffee farms bordering Mabira forest reserve in Mukono District. Jomo Kenyatta University of Agriculture and technology, Uganda

R Core Team (2015) R: A language and environment for statistical computing. R Foundation for Statistical Computing, Vienna, Austria

Radchuk V, De Laender F, Van den Brink PJ, Grimm V (2015) Biodiversity and ecosystem functioning decoupled: invariant ecosystem functioning despite non-random reductions in consumer diversity. Oikos. https://doi.org/10. 1111/oik.02220

Rahn E, Läderach P, Baca M et al (2014) Climate change adaptation, mitigation and livelihood benefits in coffee production: where are the synergies? Mitig Adapt Strat Glob Change 19:1119-1137. https://doi.org/10.1007/ s11027-013-9467-x

Rényi A (1961) On measures of entropy and information. Fourth Berkeley Symp 547:547-561

Rey Benayas JM, Bullock JM (2012) Restoration of biodiversity and ecosystem services on agricultural land. Ecosystems 15:883-899. https://doi.org/10.1007/s10021-012-9552-0

Schroth G, McNeely JA (2011) Biodiversity conservation, ecosystem services and livelihoods in tropical landscapes: towards a common agenda. Environ Manage 48:229-236 
Shen T-J, Chao A, Lin C-F (2003) Predicting the number of new species in further taxonomic sampling. Ecology 84:798-804

Tóthmérész B (1995) Comparison of different methods for diversity order. J Veg Sci 6:283-290. https://doi.org/10. 2307/3236223

Tscharntke T, Clough Y, Bhagwat SA et al (2011) Multifunctional shade-tree management in tropical agroforestry landscapes-a review. J Appl Ecol 48:619-629. https:// doi.org/10.1111/j.1365-2664.2010.01939.x

Turner HL, Firth D (2012) Bradley-Terry models in R: the BradleyTerry2 package. J Stat Softw 48:1-21

Vaast P, Harmand J-M, Rapidel B et al (2016) Coffee and cocoa production in Agroforestry-a climate-smart agriculture model. In: Torquebiau E (ed) Climate change and agriculture worldwide. Springer, Netherlands, pp 209-224

Valencia V, García-Barrios L, West P et al (2014) The role of coffee agroforestry in the conservation of tree diversity and community composition of native forests in a biosphere reserve. Agric Ecosyst Environ 189:154-163. https://doi. org/10.1016/j.agee.2014.03.024

van der Wolf J, Jassogne L, Gram G, Vaast P (2016) Turning local knowledge on agroforestry into an online decisionsupport tool for tree selection in smallholders' farms. Exp Agric. https://doi.org/10.1017/S001447971600017X (In press)

Van Noordwijk M, Hoang M, Neufeldt H et al (eds) (2011) How trees and people can co-adapt to climate change: reducing vulnerability through multifunctional agroforestry landscapes. World Agroforestry Centre (ICRAF), Nairobi

Vignola R, Harvey CA, Bautista-Solis P et al (2015) Ecosystembased adaptation for smallholder farmers: definitions, opportunities, and constraints. Agric Ecosyst Environ 211:126-132. https://doi.org/10.1016/j.agee.2015.05.013

Walther BA, Moore JL (2005) The concept of bias, precision and accuracy, and their use in testing the performance of species richness estimators, with a literature review of estimators. Ecography (Cop) 28:815-829 